\title{
Measuring Potential of Preschool Facility Staff to Prevent Early Childhood Caries
}

\author{
Danijela Jakšić-Gvozdić ${ }^{1}$, Slobodan M. Janković2, Danka Pajović ${ }^{1}$, Sandra Vidojevićs , Srđan \\ Stefanović ${ }^{4}$, Jasmina R. Milovanović ${ }^{2}$ \\ ${ }^{1}$ Department of Preventive and Pediatric Dentistry, Institute of Dentistry, Kragujevac, Serbia \\ 2Department of Pharmacology and Toxicology, Faculty of Medical Sciences, University of Kragujevac, Kragujevac, \\ Serbia \\ ${ }^{3}$ Private Dental Office, Kragujevac, Serbia \\ ${ }^{4}$ Department of Clinical Pharmacy, Faculty of Medical Sciences, University of Kragujevac, Kragujevac, Serbia
}

\section{SUMMARY}

The aim of this study was to investigate the possible potential of preschool staff through a newly designed questionnaire and evaluate their role in the prevention of early childhood caries (EEC) in Serbia where extremely high prevalence of this preventable disease was recorded.

We preformed a cross-sectional study of 268 preschool staff using specially prepared semistructured questionnaire for measuring potential of secondary children's caregivers to prevent EEC. The questionnaire was tested on a pilot sample and after that all collected data were analyzed trough construction of correlation matrix with the evaluation of the value of each question, reliability testing, factorial analysis and estimating of its validity using SPSS software.

The tested questionnaire had good internal consistency based on the Cronbach's alpha coefficient value of 0.873 calculated directly and similar value $(0.899)$ after applied Spearman-Brown "prediction" formula. Using exploratory factorial analysis and orthogonal rotation, we identified two domains that emerged with similar loadings (4.043 and 3.183). The first factor (domain) reflected attitudes of the study participants towards prevention of EEC, and the second factor (domain) showed behaviour of the study participants, which includes preventive actions against EEC.

The total score of the questionnaire was correlated positively with oral health knowledge (Spearman's correlation coefficient $0.331, \mathrm{p}=000$ ) and inversely with the length of employment, where each additional year of employment decreased the total score of the questionnaire by 1.20.

These findings could partially explain an extremely high prevalence of EEC in young children and indicate that preschool teachers should be more engaged in health education activities and motivation programs.

Key words: early childhood caries, prevention, deciduous dentition, oral health 


\section{INTRODUCTION}

Early childhood caries (EEC) is the most common infectious and chronic pediatric disease, which includes the presence of tooth decay on any primary tooth in the children aged up to six years (1). Nowadays, it is one of the current problems of public health worldwide due to its high prevalence (in some communities it exceeds 90\%) (2) and depends on geographic area, as well as the type and number of risk factors. Results of numerous studies indicate that socioeconomic, cultural and factors related to hygiene and dietary habits are leading and common risk factors to all the countries in of the world (3-8).

The acquisition of positive habits and education of children on ways of preserving oral health begins within the family (9). Apart from the family, the secondary socialization process also affects the modification of children's behaviour towards oral health where educational institutions have the leading role (10). In modern society, with children spending more than half a day in preschool institutions and consuming at least two meals there, not only is this responsibility of parents and family members, but teachers as well. The analysis of early childhood caries occurrence inside and outside preschool institutions has indicated a twice-lower prevalence of caries among children in kindergartens, regardless of the proven higher risk of spreading mutans streptococci from one child to another within a group (11). The investigations conducted in kindergartens pointing to the effect of frequent consumption of sweets between meals on the increase in ECC and its restriction, supervised tooth brushing and professional fluoride application while children are in kindergartens have proved to be significant measures in the prevention of this disease (12-16).

The fact that children, who spent considerable time in kindergartens, are integrated into the program of preventive oral health care is one of the significant reasons for lowering the prevalence and degree of severity of EEC among children whose parents are employed, especially mothers $(17,18)$. On the other hand, more severe types of ECC were more frequent among children that did not go to kindergarten, and the explanation stated is regular consumption of meals and intensive medical and educational work with children in preschool institutions, which includes not only teachers but dentists as well (11). The presence of a dentist's office in educational institutions has a positive impact on children's oral health condition but the role of preschool facilities staff is also very important. It has been observed that if they are educated and efficient, they have consequential role in cavity prevention (19).

In literature data, there is evidence of preschool teacher's lack of information and knowledge about the importance of oral health, fluoride application, regular dental checkups, consumption of sweets between meals and dental eruption chronology (20). However, educational level of preschool facilities staff varies considerably among different regions and countries, and is affected by the degree of economic and social development. Especially undeveloped and developing countries have vulnerable educational systems, which are not standardized and without defined educational outcomes. According to our knowledge, up to now, there are no studies that analyzed the role of preschool staff regarding the oral health of children and EEC in the Western Balkans.

The aim of this study was to investigate the possible potential of preschool facilities staff through a newly designed questionnaire and evaluate their role in the prevention of early childhood caries.

\section{METHODS}

This study was conducted as a cross-sectional study at the preschool institution "Nada Naumović" in the city of Kragujevac, Central region of Serbia, during the four-month period, from March to June 2014. This institution works in two shifts, it includes 15 facilities (nurseries and kindergartens), with a total of 392 preschool staff (278 preschool teachers and 114 nurses) who take care of about 4,500 children. The Ethics Committee of Institute of Dentistry at Kragujevac, Serbia approved the study.

The actual sample size was calculated with $G^{*}$ Power software (21) using the following input: two-tailed Z-test for comparing two independent proportions with alpha level of 0.05 ; power of the study of $80 \%(0.8)$; and the effect size based on assumed difference in the average incidence of correct answers to questions for measuringe potential regarding the ECC prevention between nurses and preschool teachers of at least $20 \%$ in favour of nurses, considering the incidence of the mentioned variables in the group of preschool teachers of $50 \%$. Taking into account the participants occupations in relation to the jobs performed, 3:1 ratio was determined to the advantage of preschool teachers. Based on these parameters, it was established that the study required 
at least 197 participants, out of which 148 preschool teachers and 49 nurses. These numbers were increased by $30 \%$ of those that would not complete the questionnaire according to the investigators' estimate, which means that at least 256 participants should have been surveyed.

All necessary data were collected using a paper form, semi-structured questionnaire, filled in individually by the participants from ten kindergartens, which were randomly selected. Subsequent to presenting all necessary details related to the study, both orally and in written form, participation in the study was offered to a total number of 268 preschool teachers and nurses. The only inclusion criterion fulfilled by all participants was their written consent to participate in the study.

Due to the absence of a gold standard for measuring the role of preschool staff in relation to early childhood caries, the main instrument in this study was specially designed semi-structured questionnaire by a professional research team led by a specialist in pediatric and preventive dentistry (5 and 2 , respectively). In order to achieve a better quality of estimation, the questions were formed following the detailed analysis of modern guidelines on ECC prevention, existing in countries with highlu developed systems of preventive health care (22-30). The questionnaire was divided into two parts with a total of 24 questions. The first part of the survey covered 10 questions, 6 out of which included ready answers that participants were to select by circling, and 4 required filling in the blanks and referred to socio-demographic characteristics of the participants (such as gender, age, level of education, length of service, number of working hours per day, length of continuous service in the same preschool group and the age of children concerned). The second part of the questionnaire was specially prepared for measuring potential of participants to prevent early preschool caries and included 14 multiple-choice questions with answers offered in the form of a modified three level Likert scale (31). The answers provided in the questionnaire were "strongly agree", "somewhat agree" and "strongly disagree" and were scored by 2 , 1 and 0 points for correct, partially correct and incorrect answers, respectively. In order to better understand the response from the aforementioned survey, researchers also measured the knowledge of subjects related to EEC by another brief scale, which included seven simple questions. These questions refer to well-known causes of EEC, caries prevention and importance of good oral health and primary teeth.

In accordance with the principles for construction of a new questionnaire (32-34), we engaged an expert team (with 7 members described above) for review and assessment of each question from the questionnaire, estimation of its clarity and conciseness and to carry out possible correction of the questionnaire on the whole. A newly formed questionnaire was tested on a pilot sample of 8 respondents in the preschool institution for assessment of its clarity. After that, the questionnaire was administered to the whole study sample and the data collected were analyzed by four methods: construction of correlation matrix with the evaluation of the value of each question (its correlation to the total score of the questionnaire, determining its variance and average score values), reliability testing, factorial analysis and estimating of its validity.

Reliability testing was conducted through the calculation of the Cronbanch's alpha coefficients in order to determine internal consistency of the questionnaire as a whole and its individual parts obtained after split-half method (two parts with the same number of questions randomly divided using the SSPS program). In addition, the Spearman-Brown coefficient was determined using values of Cronbach's alpha for the both parts, number of question and its mean values of coefficient of correlation. On the other hand, our newly formed questionnaire was tested for its suitability using two tests (Kaiser-Meyer-Olkin and Bartlett's test) and factor extraction was performed after orthogonal rotation (by Varimax method), using Scree-plot and the criterion that egenvalues should be greater than 1.5. The extracted factors were named according to the phenomenon they are reflecting. The validity of the applied questionnaire was tested through comparison of scores among the educational groups of the study participants.

For the purpose of statistical evaluation, the continuous variables were summarized by means and standard deviations, whereas proportions (percentage of incidence) of certain categories were used for categorical variables. Student's t-test was used for independent samples, that is, analysis of variance (ANOVA) for comparing more than two subgroups in order to determine the significance of differences in mean values of continuous variables among the compared groups of preschool teachers, and in case the distribution of values fulfilled the criteria of normality according to Kolmogorov-Smirnov test. 
Otherwise, non-parametric alternatives were used, such as Mann-Whitney test, that is, KruskallWallis test. Chi-squared test was applied to establish the significance of difference in the incidence of certain categories for descriptive characteristics among the compared groups.

The multiple linear regression model explained variability of the study outcome, and the results were displayed as coefficients for individual variables, adjusted for the other variables included in the model. The data were processed by applying the SPSS software package (SPSS for Windows, version 18.0, Chicago, Illinois). The level of statistical significance for all analyses was 5\% (0.05).

\section{RESULTS}

The total of 234 questionnaires were completed and handed back by the participants (out of 268 distributed) with response rate of $87 \%$, and their socio- demographic data are presented in Table 1. The study population consisted mostly of females (only 6 male), with a mean of 38 years (range 22 to 59 years).

The results presented in the correlation matrix show a positive correlation among all the questions (the matrix is shown in the Supplementary file), and responses were widely distributed with significant variance (Table 2). The questionnaire had good internal consistency based on Cronbach's alpha coefficient value of 0.873 for the entire questionnaire. After employment of the split-half method (two parts with the same number of questions) the values of Cronbach's were very similar to the alpha of the whole questionnaire (0.818 and 0.819, respectively). Applying the split-half method and the Spearman-Brown "prediction" formula we have obtained the value of Cronbach's alpha of 0.899 for the whole questionnaire, which is also very similar to the value calculated directly.

Validity of the questionnaire was tested through comparison of the survey results with the level of education of the participants.

Table 1. Socio-demographic data

\begin{tabular}{|c|c|c|}
\hline \multicolumn{3}{|l|}{ Variables } \\
\hline Age & Mean $(37.79 \pm 8.56)$ & $\mathrm{N}(\%)$ \\
\hline Gender & $\begin{array}{l}\text { - female } \\
\text { - male }\end{array}$ & $\begin{array}{c}228(97) \\
6(3)\end{array}$ \\
\hline Ethnicity & Serbian & $234(100)$ \\
\hline Occupation & $\begin{array}{l}\text { - preschool teacher } \\
\text { - preschool nurse } \\
\text { - p.m. nurse* }\end{array}$ & $\begin{array}{c}143(61.1) \\
78(33.3) \\
13(5.6) \\
\end{array}$ \\
\hline Education & $\begin{array}{l}\text { - secondary } \\
\text { - junior college } \\
\text { - university }\end{array}$ & $\begin{array}{l}85(36.3) \\
96(40.6) \\
54(23.1)\end{array}$ \\
\hline Length of service & $\begin{array}{l}\text { - up to } 5 y .^{*} \\
\text { - from 6-15y. } \\
\text { - from } 16-25 y . \\
\text { - over } 25 y .\end{array}$ & $\begin{array}{l}66(28.2) \\
99(42.3) \\
38(16.2) \\
31(13.2)\end{array}$ \\
\hline Length of service (cont.-same gr.) ${ }^{*}$ & $\begin{array}{l}\text { - up to } 1 \mathrm{y} . \\
\text { - from } 1-5 \mathrm{y} . \\
\text { - from } 6-15 \mathrm{y} . \\
\text { - over } 15 \mathrm{y} .\end{array}$ & $\begin{array}{c}111(47.4) \\
102(43.6) \\
9(3.8) \\
12(5.1)\end{array}$ \\
\hline Number of working hours per day & Average & 7.11 \\
\hline Number of children per group & $\begin{array}{l}\text { - from 1-10 } \\
\text { - from } 11-20 \\
\text { - from 21-30 } \\
\text { - over } 30 \\
\end{array}$ & $\begin{array}{c}2(0.9) \\
14(6) \\
132(56.4) \\
86(36.8) \\
\end{array}$ \\
\hline Age of children & $\begin{array}{c}\text { - lower nursery } \\
\text { - upper nursery } \\
\text { - lower kindergarten } \\
\text { - middle kindergarten } \\
\text { - upper kindergarten } \\
\text { - preschool } \\
\text { - mixed }\end{array}$ & $\begin{array}{c}\left(6-24 \mathrm{~m} .{ }^{*}\right) \\
(24-36 \mathrm{~m}) \\
\text { (at } 3 \mathrm{y} .) \\
\text { (at } 4 \text { y.) } \\
\text { (at } 5 \text { y.) } \\
(5.5 \text { y.-starting school) } \\
\text { (3-5.5 y.) }\end{array}$ \\
\hline
\end{tabular}

*p.m.-preventive medicine; ${ }^{*}$ length of service (cont.-same gr.)-length of service continuously in the same group;

*y.-year; ${ }^{*}$ m-month 
Table 2. Descriptive statistics of responses to questions about attitudes and behaviour of the preschool staff

\begin{tabular}{|c|c|c|c|c|}
\hline Question & $\begin{array}{l}\text { Mean } \\
\text { value }\end{array}$ & $\begin{array}{l}\text { Standard } \\
\text { deviation }\end{array}$ & $\begin{array}{l}\text { Minimal } \\
\text { value }\end{array}$ & Maximal value \\
\hline 1.ECC is a preventable disease & 1.50 & 0.588 & 0 & 2 \\
\hline $\begin{array}{l}\text { 2.ECC can be prevented by practising good oral hygiene with } \\
\text { children and by using fluoride toothpaste }\end{array}$ & 1.68 & 0.503 & 0 & 2 \\
\hline $\begin{array}{l}\text { 3.Supervision and assistance in personal hygiene } \\
\text { maintenance are recommended for children up to the } \\
\text { minimum age of eight }\end{array}$ & 1.79 & 0.478 & 0 & 2 \\
\hline $\begin{array}{l}\text { 4.Repairing decayed milk teeth is necessary because it } \\
\text { reduces the possible occurrence of complications }\end{array}$ & 1.76 & 0.543 & 0 & 2 \\
\hline $\begin{array}{l}\text { 5.Children should go for dental visits every 3-6 months, } \\
\text { with at least one of those checkups being in kindergarten } \\
\text { premises in cooperation with the attending dentist }\end{array}$ & 1.82 & 0.472 & 0 & 2 \\
\hline $\begin{array}{l}\text { 6. Health education lectures and motivational interviews } \\
\text { aimed at parents/caregivers and educational institutions staff } \\
\text { can reduce the incidence of ECC }\end{array}$ & 1.76 & 0.459 & 0 & 2 \\
\hline $\begin{array}{l}\text { 7. Coordinated cooperation among dentists, } \\
\text { parents/caregivers and preschool teachers can reduce the } \\
\text { incidence of ECC }\end{array}$ & 1.82 & 0.430 & 0 & 2 \\
\hline $\begin{array}{l}\text { 8. I provide parents with information on the relevant } \\
\text { dentist's office }\end{array}$ & 1.89 & 0.395 & 0 & 2 \\
\hline $\begin{array}{l}\text { 9. In view of the fact that oral health of children in my care is } \\
\text { my responsibility as well, I detect changes in their teeth and } \\
\text { inform parents of the matter }\end{array}$ & 1.60 & 0.586 & 0 & 2 \\
\hline $\begin{array}{l}\text { 10. By using available means of information outreach } \\
\text { (posters, brochures, model teeth, videos, etc. ), I point out the } \\
\text { importance of oral hygiene and oral health to children }\end{array}$ & 1.75 & 0.514 & 0 & 2 \\
\hline $\begin{array}{l}\text { 11. Once a year I organise creative workshops as part of } \\
\text { participating in manifestations marking the dental health } \\
\text { week }\end{array}$ & 1.50 & 0.663 & 0 & 2 \\
\hline $\begin{array}{l}\text { 12. During multi-day excursions I monitor children's } \\
\text { consumption of candy, savoury snacks and sweetened } \\
\text { beverages, as well as oral hygiene maintenance }\end{array}$ & 1.55 & 0.655 & 0 & 2 \\
\hline $\begin{array}{l}\text { 13. In cooperation with a dentist I participate in the } \\
\text { supervision and demonstration of correct teeth brushing } \\
\text { technique for preschool children in kindergarten premises } 14\end{array}$ & 1.53 & 0.700 & 0 & 2 \\
\hline $\begin{array}{l}\text { 14. I try to gain new and improve my existing knowledge } \\
\text { about dental injuries and diseases in cooperation with } \\
\text { dentists }\end{array}$ & 1.71 & 0.502 & 0 & 2 \\
\hline
\end{tabular}


Table 3. Results of multiple linear regression

\begin{tabular}{|c|c|c|c|c|c|c|}
\hline Model & & $\overline{\text { B }}$ & $\begin{array}{l}\text { Std. } \\
\text { Error }\end{array}$ & Beta & $\bar{t}$ & p value \\
\hline \multirow[t]{10}{*}{1} & (Constant) & 24,382 & 2.835 & & 8.600 & .000 \\
\hline & Age & .738 & .674 & .100 & 1.095 & .275 \\
\hline & Gender & 1.140 & 1.938 & .039 & .588 & .557 \\
\hline & Education & -.001 & .651 & .000 & -.002 & .998 \\
\hline & Length of service & -1.177 & .443 & -.247 & -2.654 & .009 \\
\hline & $\begin{array}{l}\text { Number of working hours } \\
\text { per day }\end{array}$ & -.115 & .310 & -.025 & -.370 & .712 \\
\hline & $\begin{array}{l}\text { Number of children per } \\
\text { group }\end{array}$ & .421 & .505 & .056 & .835 & .405 \\
\hline & Occupation & -.602 & .832 & -.077 & -.724 & .470 \\
\hline & $\begin{array}{l}\text { Length of service (cont.- } \\
\text { same gr.) }\end{array}$ & -.165 & .474 & -.028 & -.347 & .729 \\
\hline & Age of children & .027 & .148 & .013 & .181 & .857 \\
\hline \multirow[t]{9}{*}{2} & (Constant) & 24.380 & 2.433 & & 10.021 & .000 \\
\hline & Age & .738 & .660 & .100 & 1.118 & .265 \\
\hline & Gender & 1.140 & 1.933 & .039 & .589 & .556 \\
\hline & Length of service & -1.177 & .442 & -.247 & -2.660 & .008 \\
\hline & $\begin{array}{l}\text { Number of working } \\
\text { hours per day }\end{array}$ & -.115 & .309 & -.025 & -.371 & .711 \\
\hline & $\begin{array}{l}\text { Number of children per } \\
\text { group }\end{array}$ & .421 & .500 & .056 & .843 & .400 \\
\hline & Occupation & -.601 & .567 & -.077 & -1.060 & .290 \\
\hline & $\begin{array}{l}\text { Length of service (cont.- } \\
\text { same gr.) }\end{array}$ & -.165 & .470 & -.028 & -.350 & .726 \\
\hline & Age of children & .027 & .142 & .013 & .187 & .852 \\
\hline \multirow[t]{8}{*}{3} & (Constant) & 24.449 & 2.400 & & 10.188 & .000 \\
\hline & Age & .739 & .659 & .100 & 1,122 & .263 \\
\hline & Gender & 1.166 & 1.924 & .040 & .606 & .545 \\
\hline & Length of service & -1.176 & .441 & -.247 & -2.663 & .008 \\
\hline & $\begin{array}{l}\text { Number of working hours } \\
\text { per day }\end{array}$ & -.117 & .308 & -.025 & -.379 & .705 \\
\hline & $\begin{array}{l}\text { Number of children per } \\
\text { group }\end{array}$ & .431 & .496 & .057 & .869 & .386 \\
\hline & Occupation & -.621 & .555 & -.080 & -1.118 & .265 \\
\hline & $\begin{array}{l}\text { Length of service (cont.- } \\
\text { same gr.) }\end{array}$ & -.138 & .447 & -.023 & -.309 & .758 \\
\hline \multirow[t]{7}{*}{4} & (Constant) & 24.439 & 2.395 & & 10.205 & .000 \\
\hline & Age & .724 & .656 & .098 & 1.105 & .270 \\
\hline & Gender & 1.192 & 1.919 & .040 & .621 & .535 \\
\hline & Length of service & -1.205 & .430 & -.253 & -2.800 & .006 \\
\hline & $\begin{array}{l}\text { Number of working hours } \\
\text { per day }\end{array}$ & -.113 & .307 & -.025 & -.369 & .712 \\
\hline & $\begin{array}{l}\text { Number of children per } \\
\text { group }\end{array}$ & .416 & .493 & .055 & .844 & .400 \\
\hline & Occupation & -.676 & .525 & -.087 & -1.287 & .199 \\
\hline
\end{tabular}

Legend: B - unstandardized coefficients, beta - standardized coefficients, $R^{2}=0.058$ for models 1,2,3 and 4 . 
It turned out that the total score of the questionnaire was not dependent on the level of education of the respondents $(\mathrm{p}=0.141)$.

The factorial analysis was feasible because KaiserMeyer-Olkin test of 0.842 confirmed sampling adequacy and the value of the Bartlett's test of sphericity was highly significant $\left(\chi^{2}=1367,610 ; \mathrm{df}=91 ; \mathrm{p}=0.000\right)$. After Varimax method of orthogonal rotation, two factors emerged with similar loadings (4.043 and 3.183), each of them having 7 items. The first factor (domain) reflects attitudes of the study participants towards prevention of early childhood caries, and the second factor (domain) shows behaviour of the study participants, which includes preventive actions against early childhood caries.

Multiple linear regression was built on nine independent variables (showed in Table 3) which could have influenced the total score of the questionnaire. The final model was reached by a backward deletion method, and included six independent variables (age, sex, occupation, length of service, number of working hours per day, number of children in the group). The model explained $5.8 \%$ of the variability of the total score $(\mathrm{F}=2.314, \mathrm{p}=0.035)$. The only variable with significant influence on the total score was the length of employment in a preschool facility $(B=-1.205 \pm 0.430, p=$ 0.006). Each additional year of employment decreases the total score of the questionnaire for 1.205.

Knowledge was measured by the 7-item questionnaire, and the answers were rated as 1 (incorrect) and 2 (correct). The total mean score for the knowledge about ECC amounted to $10.28 \pm 2.81$ (range $0-14)$. The participant's age, gender, education, length of service and length of continuous service with children in the same preschool group did not have influence on the knowledge score (the results are not shown). However, there was statistically significant difference $(p=0.006)$ in terms of participants occupations. Nurses demonstrated greater knowledge about ECC compared to preschool teachers. Furthermore, knowledge of participants significantly correlated with the total score of the questionnaire (Spearman's correlation coefficient $0.331, \mathrm{p}$ =000) (Figure 1, Table 4).

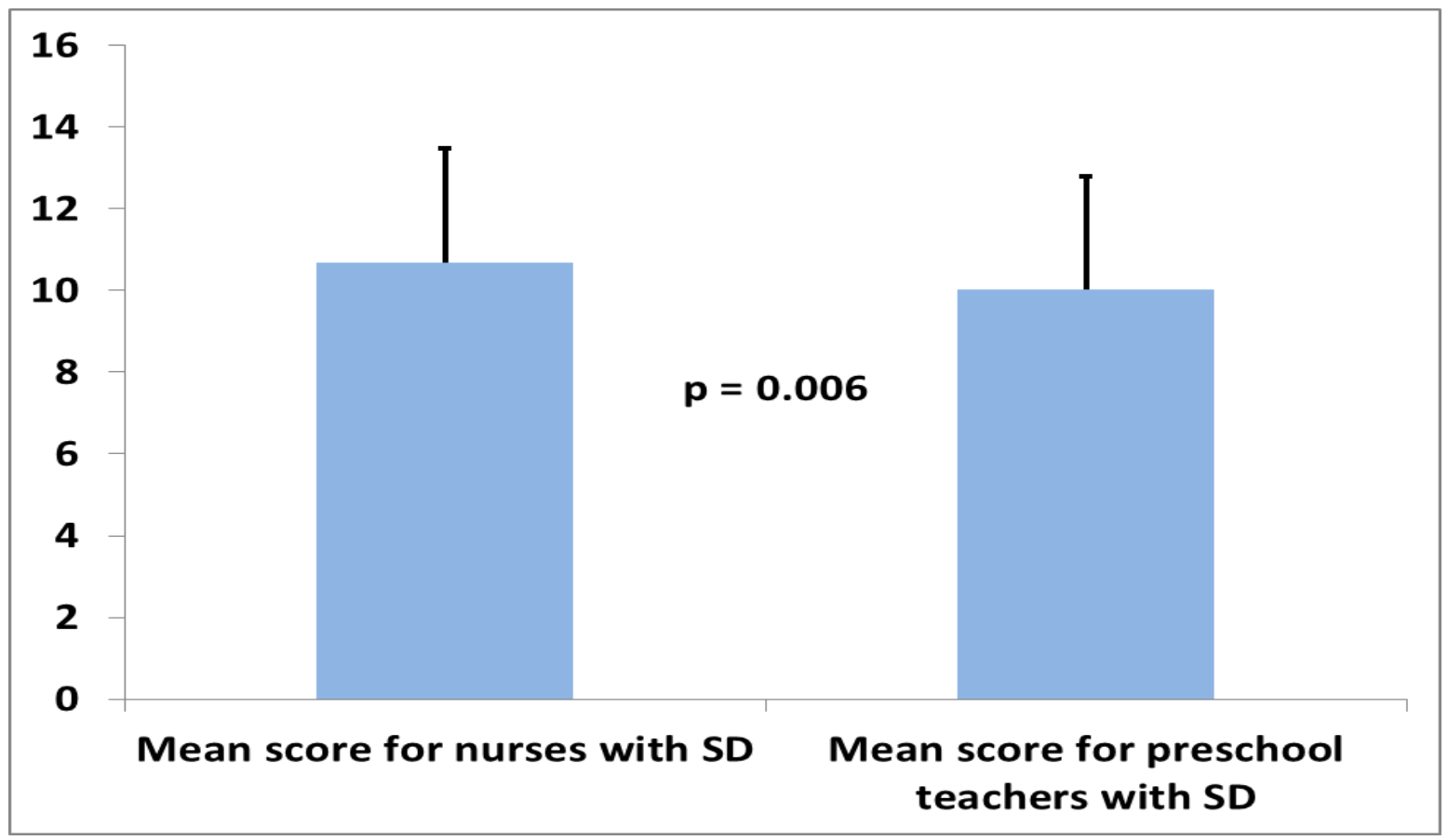

Figure 1. The total mean scores for the knowledge of participants about ECC 
Table 4. Correlation matrix

\begin{tabular}{l|l|l|l|l|l|l|l|l|l|l|l|l|l|l}
\hline \hline & Q1 & Q2 & Q3 & Q4 & Q5 & Q6 & Q7 & Q8 & Q9 & Q10 & Q11 & Q12 & Q13 & Q14 \\
\hline Q1 & 1.000 & .341 & .198 & .363 & .209 & .247 & .297 & .324 & .181 & .043 & .198 & .229 & .031 & .211 \\
\hline Q2 & .341 & 1.000 & .338 & .331 & .414 & .534 & .441 & .410 & .265 & .322 & .268 & .265 & .301 & .270 \\
\hline Q3 & .198 & .338 & 1.000 & .497 & .537 & .407 & .413 & .401 & .293 & .342 & .206 & .364 & .211 & .201 \\
\hline Q4 & .363 & .331 & .497 & 1.000 & .641 & .351 & .454 & .481 & .388 & .309 & .158 & .397 & .188 & .291 \\
\hline Q5 & .209 & .414 & .537 & .641 & 1.000 & .337 & .475 & .567 & .290 & .422 & .311 & .286 & .334 & .397 \\
\hline Q6 & .247 & .534 & .407 & .351 & .337 & 1.000 & .642 & .424 & .388 & .252 & .208 & .349 & .230 & .209 \\
\hline Q7 & .297 & .441 & .413 & .454 & .475 & .642 & 1.000 & .592 & .356 & .414 & .296 & .361 & .225 & .265 \\
\hline Q8 & .324 & .410 & .401 & .481 & .567 & .424 & .592 & 1.000 & .391 & .524 & .354 & .378 & .252 & .360 \\
\hline Q9 & .181 & .265 & .293 & .388 & .290 & .388 & .356 & .391 & 1.000 & .355 & .275 & .305 & .264 & .242 \\
\hline Q10 & .43 & .322 & .342 & .309 & .422 & .252 & .414 & .524 & .355 & 1.000 & .506 & .446 & .521 & .364 \\
\hline Q11 & .198 & .268 & .206 & .158 & .311 & .208 & .296 & .354 & .275 & .506 & 1.000 & .484 & .522 & .397 \\
\hline Q12 & .229 & .265 & .364 & .397 & .286 & .349 & .361 & .378 & .305 & .446 & .484 & 1.000 & .586 & .379 \\
\hline Q13 & .031 & .301 & .211 & .188 & .334 & .230 & .225 & .252 & .264 & .521 & .522 & .586 & 1.000 & .495 \\
\hline Q14 & .211 & .270 & .201 & .291 & 3.97 & .209 & .265 & .360 & .242 & .364 & .397 & .379 & .495 & 1.000 \\
\hline \hline
\end{tabular}

\section{DISCUSSION}

Early childhood caries is a disease which is often followed by complications, such as chronic pulpitis or apical periodontitis, and can cause severe pain that affects children's quality of life (disturbing their daily activities, eating, sleeping) but also affects the physical and mental development (35). Epidemiological studies showed the medium prevalence of this illness in the Balkan countries (approximately $30 \%$ in Bulgaria, Croatia and the northen region of Serbia) (11) and a positive correlation between the age of a child and severity of EEC, but results of recent study conducted in the central region of Serbia have showen an extremely high prevalence of EEC (up to 96,08\%) in children aged 6-7 years (36). Since EEC is preventable disease, timely implementation of preventive measures at all levels (from the family to the state) is very important. It is especially true for preschool facilities, where engagement of healthcare staff in preventive activities is of key importance.

The main result of our study was the development of a new questionnaire, especially adapted to socioeconomic and cultural background of Serbia, a Western Balkan country, which could efficiently measure the engagement of pre-school facility staff in the prevention of this highly frequent disease. The questionnaire was composed of 14 questions, and achieved good internal consistency with high value of Cronbach's alpha coefficient. Factorial analysis revealed two clearly separated domains, one reflecting attitude and another behaviour of teachers and nurses employed in kindergartens devoted to prevention of early childhood caries. Such results of initial testing of the questionnaire look promising, and open a possibility to use it in new studies as a tool, or to measure effectiveness of various initiatives to improve the engagement of preschool facility's staff in the prevention of childhood caries.

Not surprisingly, many researchers pointed to diverse factors that influence attitudes and behaviour concerning EEC in different populations, like prolonged breast-feeding, frequent consumption of sweets, presence of cariogenic bacteria, parental education as well as caregivers' oral health knowledge (35). Our study confirmed only one factor with significant influence: longer duration of employment at preschool facilities led to a more negative attitude and rather passive behaviour of healthcare staff in relation to the EEC.

Detailed analysis of completed questionnaires in our study concerning the attitude domain showed that $76 \%$ of the participants had correct attitudes about to early childhood caries, and majority of the participants (over eighty percent) realized the importance of close cooperation with both dentists and parents, of children's regular visits to dental clinics, repairing primary teeth and assisting to children in maintenance of oral hygiene. Satisfactory level of understanding the importance of educational lessons by professionals (77\%) has also been recorded. On the other hand, although over three quarters of the study participants were aware of the importance of repairing decayed primary teeth, which was a significantly better result than in other studies (33\%, $40 \%$ and $74 \%$ among caregivers in Poland,Malaysia and England, respectively) $(19,37)$ and although they knew that children need supervision of tooth brushing, less than $70 \%$ believed that using toothpaste with fluoride can prevent the development 
of this disease and only half thought about EEC as of a preventable disease. Inadequate answers to these questions have direct adverse influence on the implementation of preventive measures that are expected of preschool staff. This could be the result of low general knowledge about oral health that we found in our study. Since regular tooth brushing with toothpaste containing fluoride is a very efficient method of prevention of caries (it is prevents $20-30 \%$ of caries in other countries (38), it is a pity that an important chance is lost for them to acquire healthy habits with the help of a preschool teacher. It should be emphasized that children do not have their personal toothbrushes and toothpaste in the investigated preschool facilities, although they spend there eight to twelve hours daily, which could be an additional reason for avoiding supervised tooth brushing as a daily routine.

Behaviour of caregivers is one of the crucial factors in maintenance of oral hygiene and the overall oral health in young children because they are entirely dependent on it. Further, positive behaviour can play an important role of a protective factor for primary tooth caries (39). Concerning the total score of the behaviour domain of the questionnaire, about $70 \%$ of the respondents gave agreeable answers, but the average score was slightly lower compared to the score of the attitude domain $(11.54 \pm 2.82$ vs. $12.24 \pm 2.41)$. As to the activities, between $60 \%$ and $65 \%$ of the respondents claimed to organize creative workshops with the idea of highlighting the importance of dental health, monitoring consumption of sweets during vacation and assisting dentists when demonstrating tooth brushing during their fieldwork visits. However, the percentage of those capable of detecting decayed primary teeth was rather low $(65 \%)$, so it is necessary for them to attend special training sessions in cooperation with professionals. Previous studies showed that primary and secondary caregivers sought professional dental care mainly for children with severe symptoms of tooth decay $(35,40$, 41). These results indicate that caregivers generally make inadequate efforts to monitor children's dental health status, promote and implement preventive programs related to EEC. Once trained to identify caries, preschool teachers could warn parents to take a child to a dentist on time, and thus contribute significantly to early detection and prevention of ECC. We found that approximately eighty percent of the preschool staff used at least some source of information for educating children with respect to oral hygiene and oral health in general, but what the actual sources were (pamphlets, flyers, videos, or else) remained unanswered. Earlier studies showed that majority of parents and secondary caregivers used information about oral health from advertisements and newspapers rather than from the health professionals or other trusted sources (35).

It is encouraging that high percentage (92\%) of the study participants used to refer parents to a dentist's office. Only professionals could make reliable diagnosis of caries and provide necessary and efficient treatment. It is also a good opportunity to establish a direct contact between the dentist and parents on the one hand, and the dentist and a child on the other, which is essential for building mutual trust. Setting of a reliable preschool teacher-parent-dentist chain is an important step in implementing preventive measures, as well as in preventing further progression and complications related to this disease.

At least, the basic level of knowledge about oral health, especially about early childhood caries is an important requirement for the prevention of this disease, which heavily influences the attitudes and behaviour of each individual who takes care of children. Although parents have primary responsibility for undertaking early preventive and correctional oral interventions, secondary caregivers also have an important role (42). In our study, the knowledge score correlated well with the total score of the questionnaire measuring attitudes and behaviour, confirming once more an important link between knowledge and attitudes and behaviour concerning the EEC. However, general knowledge about oral health was rather low: only about $60 \%$ of answers to very basic questions were correct. Yet, nurses achieved higher scores, as expected, since their previous education had provided more information on this topic. Only twelve percent of the surveyed population knew that ECC is actually an infectious disease, which could be transmitted via cavity-causing bacteria from caregivers to children. These results are similar to that of Mani et al. who noted that only $15 \%$ of the surveyed participants were familiar with the role of bacteria in caries etiology (19); the other studies found somewhat higher percentages: from $33 \%$ to $46 \%(19,35)$. It is obvious that concepts of vertical and horizontal bacterial transmission are not properly addressed within formal education about oral health.

When it comes to the question about the effects of prolonged breastfeeding and consumption of sweetened beverages by bottle-feeding on cavity development, the knowledge scores were satisfactory (sixty-four percent caregivers were familiar with this fact). These factors have been identified in numerous studies as very influential to caries risk and severity of the disease; 
unfortunately, the level of mothers's knowledge about them was frequently low (they were not aware of the hidden sugars in breast milk) $(19,35,43)$.

Analysis of socio-demographic characteristics of the respondents and of their protective influence on dental caries showed that out of the ten accounted variables, only the length of the service affected the overall score of the questionnaire. Previous studies had found that the level of education of caregivers, especially mothers, was notably associated with undertaking preventive measures in children (44-46). In our study, the education of caregivers was relatively high: $63 \%$ of participants had university degree and the others were high school graduates. Paradoxically, the length of employment was associated with lower total score of the questionnaire for measuring attitudes and behaviours (it dropped by 1.2 by each year of the employment). This result could be explained by gradual reduction of working enthusiasm over time. In fact, the young staff members are generally the most motivated in carrying out their duties and keen to transfer acquired knowledge to children and parents. Although Serbia formally belongs to the country with the upper middle income, economic conditions were unfavorable for several decades, with stagnant salaries and increasing costs of life. In addition, unsatisfactory working conditions should also be stressed, since one staff member takes care of twelve children. All this greatly affects a general ability to work and especially motivation of employees. Many studies have identified socio-economic status of caregivers as one of the most important risk factors for missing activities directed to prevention of this disease (47-49).
Overall, our results indicate that preschool teachers should be more engaged in health education activities such as: organising lectures and educational workshops for children and parents, addressing oral health, daily practice of tooth brushing, and supervised use of fluoride products. There is also a need for designing an educational program about oral health for preschool teachers, in accordance with the recommendations of contemporary guidelines and identified risk factors, as well as the need for training sessions that would enhance their work efficiency, skills and motivation to promote oral health and prevent early childhood caries. Our study also had several limitations: (1) scores of the questionnaire did not correlate with the level of education of the respondents (presence of high homogeneity of population). (2) There was no "gold standard" available to compare our results with. It also cannot be excluded that the respondents gave the socially acceptable answers on purpose, leading to potential bias.

\section{CONCLUSIONS}

The score of our reliable questionnaire for measuring attitudes and behaviour of preschool staff in relation to prevention of early childhood caries was correlated positively with the general knowledge about oral health and inversely with the length of employment. These findings could partially explain an extremely high prevalence of early childhood caries in young children recently recorded in the central region of Serbia.

\section{References}

1. Jaksic Gvozdic D, Milovanović J. Socioeconomic significance and prevention of early childhood caries. Acta stomatologica Naissi 2014; 30(69):1362-72.

2. American Academy of Pediatrics, Committee on Native American Child Health, Canadian Paediatric Society, First Nations, Inuit and Métis Committee. Early childhood caries in indigenous communities.Pediatrics 2011； 127(6): 1190-8. http://dx.doi.org/10.1542/peds.2011-0847
3. Caufield PW, Li Y, Bromage TG. Hypoplasiaassociated severe early childhood caries-a proposed definition. J Dent Res 2012; 91(6): 544-50. http://dx.doi.org/10.1177/0022034512444929

4. Losso EM, Travers MC, Silva JY et al. Severe early childhood caries: an integral approach. J Pediatr (RioJ) 2009; 85(4): 295-300. http://dx.doi.org/10.1590/S0021$\underline{75572009000400005}$ 
5. Oliveira AF, Chaves AM, Rosenblatt A. The influence of enamel defects on the development of early childhood caries in a population with low socioeconomic status: a longitudinal study. Caries Res 2006; 40(4): 296-302. http://dx.doi.org/10.1159/000093188

6. Slabsinskiene E, Milciuviene S, Narbutaite J et al. Severe early childhood caries and behavioral risk factors among 3-year-old children in Lithuania. Medicina (Kaunas) 2010; 46(2): 135-41.

7. Kressin NR, Nunn ME, Singh $H$ et al. Pediatric clinicians can help reduce rates of early childhood caries: effects of a practice based intervention. Med Care 2009; 47(11): 1121-8. http://dx.doi.org/10.1097/MLR.0b013e3181b58867

8. Ribeiro NM, Ribeiro MA. Breastfeeding and early childhood caries: a critical review. J Pediatr (Rio J). 2004; 80 (5Suppl): S199-210. http://dx.doi.org/10.1590/S0021$\underline{75572004000700012}$

9. Kostadinović Lj, Aleksić B, Igić M et al. Medical, social, and economic significance of school dental care service. Acta Stomatologica Naissi 2011; 27 (63): 1043-58.

10. Lalić M, Aleksić E, Gajić M et al. Oral health related knowledge and health behavior of parents and school children. Medical examination 2013; 66(1-2): 70-9.

11. Tušek I, Carević M, Tušek J. Influence of Social Environment on Caries Prevalence in Early Childhood. Srp Arh Celok Lek 2011; 139(1-2): 1824.

\section{http://dx.doi.org/10.2298/SARH1102018T}

12. Chu $\mathrm{CH}$, Ho PL, Lo EC. Oral health status and behaviors of preschool children in Hong Kong. BMC Public Health 2012; 12: 767. http://dx.doi.org/10.1186/1471-2458-12-767

13. Begzati A, Berisha M, Meqa K. Early childhood caries in preschool children of Kosovo - a serious public health problem. BMC Public Health 2010;10:788

http://dx.doi.org/10.1186/1471-2458-10-788

14. Staśkiewicz T. Analysis of the influence of some factors on the intensity of early childhood caries. Ann Acad Med Stetin 2012; 58(2): 36-9.

15.Schiffner U. Influence of caries preventive measures on prevalence and incidence of caries in Hamburg preschool children. DtschZahnarztl Z 1989; 44(7): 531-5.

16. Andruskeviciene V, Milciuviene S, Bendoraitiene Eet al. Oral health status and effectiveness of caries prevention program in kindergartens in Kaunas city (Lithuania). Oral Health Prev Dent 2008; 6(4): 343-8.

17. Kummer SC, Giugliani ER, Susin LO et al. Evolution of breastfeeding pattern. Rev SaudePublica 2000; 34(2): 143-8.

18. Lawoyin TO, Olawuyi JF, Onadeko MO. Factors associated with exclusive breastfeeding in Ibadan, Nigeria. J Hum Lact 2001; 17(4): 321-5. http://dx.doi.org/10.1177/089033440101700406

19. Mani SA, Aziz AA, John J et al. Knowledge, attitude and practice of oral health promoting factors among caretakers of children attending day-care centers in KubangKerian, Malaysia: a preliminary study. J Indian Soc Pedod Prev Dent 2010; 28(2): 78-83.

http://dx.doi.org/10.4103/0970-4388.66741

20. Begzati A, Kastriot M, Siegenthalerc D et al. Dental Health Evaluation of Children in Kosovo. Eur J Dent 2011; 5(1): 32-9.

21. Faul F, Erdfelder E, Lang A-G et al. G*Power 3: A flexible statistical power analysis program for the social, behavioral, and biomedical sciences. Behav Res Methods 2007; 39, 175-91. http://dx.doi.org/10.3758/BF03193146

22. US Department of Health and Human Services. Oral Health in America: A Report of the Surgeon General- Executive Summary.Rockville, MD: US 
Department of Health and Human Services, National Institute of Dental and Craniofacial Research, National Institutes of Health. 2000.

23. American Academy of Pediatrics. Oral health risk assessment timing and establishment of the dental home. Pediatrics 2003; 111(5): 1113-6. http://dx.doi.org/10.1542/peds.111.5.1113

24. American Academy of Pediatric Dentistry. Definition of early childhood caries (ECC). 2008. (Available at: http://www.aapd.org/assets/1/7/D_ECC.pdf. Accessed November30, 2015.)

25. European Archives of Paediatric Dentistry. Guidelines on the use of fluoride in children: an EAPD policy document. 2009.

26. American Academy of Paediatric Dentistry. Guideline on Perinatal Oral Health Care.2011.(Available at: http://www.guideline.gov/content.aspx?id=34769 Accessed November 30, 2015.)

27. American Academy of Paediatric Dentistry. Guideline on infant oral health care. 2011. (Available at: http://www.guideline.gov/content.aspx?id=34768 Accessed January 15, 2016.)

29. American Academy of Pediatric Dentistry. Guideline on Caries-risk Assessment and Management for Infants, Children and Adolescents, 2013. (Available at: http://www.aapd.org/media/Policies_Guidelines /G_CariesRiskAssessment.pdf.Accessed Januaru17, 2016.)

31. Suresh BS, Ravishankar TL, Chaitra TR et al. Mother's knowledge about pre-school child's oral health. J Indian SocPedodPrev Dent 2010; 28(4): $282-7$.

http://dx.doi.org/10.4103/0970-4388.76159

32. Streiner DL, Norman GR. Health Measurement Scales - a practical guide to their development and use. 4th edition. Oxford University Press.
Oxford; 2008.

http://dx.doi.org/10.1093/acprof:oso/97801992318 $\underline{81.001 .0001}$

33. Robert F, DeVellis. Scale Development: Theory and Applications. Third Edition. Thousand Oaks, CA: SAGE Publications, Inc; 2011.

34. Litwin, M. How to Measure Survey Reliability and Validity. Thousand Oaks, CA: SAGE Publications, Inc. 1995. http://dx.doi.org/10.4135/9781483348957

35. Wulaerhan J, Abudureyimu A, Bao XL et al. Risk determinants associated with early childhood caries in Uygur children: a preschool-based cross-sectional study. BMC Oral Health.2014;14: 136.

http://dx.doi.org/10.1186/1472-6831-14-136

36. Vidojević S, Branković B, Golijanin R. Prevalence of milk teeth caries among preschool children in urban and suburban areas in the territory of Kragujevac. Rational therapy 2012; 4(2): 35-9.

37. Szatko F, Wierzbicka M, Dybizbanska E et al. Oral health of Polish three-year-olds and mothers' oral health-related knowledge. Community Dent Health 2004; 21(2): 175-80.

38. Twetman S. Prevention of Early Childhood Caries (ECC)-Review of literature published 1998-2007. Eur Arch Paediatr Dent 2008; 9(1): 12-18.

http://dx.doi.org/10.1007/BF03321590

39. Ferreira SH, Beria JU, Kramer PF et al. Dental caries in 0-to 5-year-old brazilian children: Prevalence, severity, and associated factors. Int J Paediatr Dent 2007; 17(4): 289-96. http://dx.doi.org/10.1111/j.1365263X.2007.00831.x

40. Naidu R, Nunn J, Kelly A. Socio-behavioural factors and early childhood caries: a crosssectional study of preschool children in central Trinidad. BMC Oral Health 2013; 13(1): 30. http://dx.doi.org/10.1186/1472-6831-13-30 
41. Hashim R, Williams S, Thomson WM. Severe early childhood caries and behavioral risk indicators among young children in Ajman, United Arab Emirates. Eur Arch Paediatr Dent 2011; 12(4): 205-10.

http://dx.doi.org/10.1007/BF03262808

42. Southward LH, Robertson A, Wells-Parker E et al. Oral health status of Mississippi delta 3- to 5year-olds in childcare: an exploratory study of dental health status and risk factors for dental disease and treatment needs. J Public Health Dent 2006; 66(2): 131-7.

http://dx.doi.org/10.1111/j.17527325.2006.tb02568.x

43. Bissar A, Schiller P, Wolff A et al. Factors contributing to severe early childhood caries in south-west Germany. Clin Oral Investig 2014; 18(5):1411-8.

http://dx.doi.org/10.1007/s00784-013-1116-y

44. Schroth RJ, Halchuk S, Star L. Prevalence and risk factors of caregiverreported Severe Early Childhood Caries in Manitoba First Nationschildren: results from the RHS Phase 2 (2008-2010). Int J Circumpolar Health 2013; 5: 72-82.
45. Ramos-Gomez FJ, Weintraub JA, Gansky SA et al. Bacterial, behavioral and environmental factors associated with early childhood caries. J Clin Pediatr Dent 2002; 26(2): 165-73. http://dx.doi.org/10.17796/jcpd.26.2.t6601j361867 $\underline{5326}$

46. Nobile CG, Fortunato L, Bianco A et al. Pattern and severity of early childhood caries in Southern Italy: a preschool-based cross-sectional study. BMC Public Health 2014; 14(1): 206. http://dx.doi.org/10.1186/1471-2458-14-206

47. Li Y, Zhang $\mathrm{Y}$, Yang $\mathrm{R}$ et al. Associations of social and behavioural factors with early childhood caries in Xiamen city in China. Int J Paediatr Dent 2011; 21(2): 103-11. http://dx.doi.org/10.1111/j.1365263X.2010.01093.x

48. King NM, Wu II, Tsai JS. Caries prevalence and distribution, and oral health habits of zero- to four-year-old children in Macau, China. J Dent Child (Chic) 2003; 70(3): 243-6.

49. Uribe S. Early childhood caries-risk factors. Evid Based Dent 2009; 10(2): 37-8. http://dx.doi.org/10.1038/sj.ebd.6400642 


\title{
Merenje potencijala predškolskog osoblja u prevenciji karijesa ranog detinjstva
}

\author{
Danijela Jakšić-Gvozdić1, Slobodan M. Janković ${ }^{2}$, Danka Pajović ${ }^{1}$, Sandra Vidojević3 \\ Srđan Stefanović ${ }^{4}$ Jasmina R. Milovanović ${ }^{2}$
}

${ }^{1}$ Odsek za preventivnu $i$ dečju stomatologiju, Zavod za stomatologiju, Kragujevac, Srbija

${ }^{2}$ Odsek za farmakologiju i toksikologiju, Fakultet medicinskih nauka, Univerzitet u Kragujevcu, Kragujevac, Srbija

${ }^{3}$ Privatna stomatološka ordinacija, Kragujevac, Srbija

${ }^{4}$ Odsek za kliničku farmaciju, Fakultet medicinskih nauka, Univerzitet u Kragujevcu, Kragujevac, Srbija

\section{SAŽETAK}

Cilj ove studije bio je da ispita mogući potencijal osoblja koje radi sa decom predškolskog uzrasta upotrebom novoformiranog upitnika i proceni njihovu ulogu u prevenciji karijesa u ranom detinjstvu (KRD) u Srbiji, gde je inače zabeležena izuzetno visoka prevalencija ovog oboljenja.

Sprovedena je studija preseka na uzorku od 268 ispitanika, primenom specijalno konstruisanog polu-strukturisanog upitnika za merenje potencijala sekundarnih staralaca dece u prevenciji KRD-a. Upitnik je prvo testiran na pilot uzorku, a zatim su svi prikupljeni podaci analizirani izgradnjom korelacionog matriksa za procenu vrednosti svakog pitanja, testom pouzdanosti, faktorskom analizom $i$ procenom njihove validnosti uz upotrebu SPSS softvera.

Primenjeni upitnik je imao dobru internu konzistenciju baziranu na vrednosti Kronbahovog alfa koeficijenta od 0,873 izračunatog direktno i sličnoj vrednosti $(0,899)$ dobijenoj primenom Spirman-Braunove "predviđajuće" formule. Primenom eksplorativne faktorske analize i ortogonalne rotacije identifikovana su dva domena koja su se izdvojila sa sličnim vrednostima $(4,043$ i 3,183). Prvi faktor (domen) je odražavao stavove ispitanika vezanih za prevenciju KRD-a, dok je drugi faktor pokazivao ponašanje ispitanika, uključujući prventivne mere za sprečavanje nastanka KRD-a Ukupni skor upitnika je pozitivno korelirao sa znanjem o oralnom zdravlju (Spirmanov koeficijent korelacije $0,331, p=000$ ), a inverzno sa dužinom radnog staža, gde je svaka dodata godina radnog staža smanjivala ukupnu vrednost upitnika za 1,20.

Ovi rezultati mogu delimično objasniti izuzetno visoku prevalenciju KRD-a kod male dece i ukazaju da bi vaspitači trebalo da budu više uključeni u zdravstveno vaspitne aktivnosti i motivacione programe.

Ključne reči: karijes u ranom detinjastvu, prevencija, primarna denticija, oralno zdravlje 